\title{
PENGEMBANGAN TEKNIK PEMBELAJARAN PASING BAWAH PERMAINAN BOLA VOLI SMP KELAS VII
}

\author{
Destriana $^{1)}$, Destriani ${ }^{2)}$, dan Herri Yusfi ${ }^{2)}$ \\ ${ }^{1,2,3}$ Pendidikan Jasmani dan Kesehatan, Fakultas Keguruan dan Ilmu Pendidikan, Universitas Sriwijaya \\ Jl. Palembang-Prabumulih, Km 32 Inderalaya, kabupaten Ogan Ilir, 30662 \\ Email: destriana@fkip.unsri.ac.id ${ }^{1)}$, destriani@fkip.unsri.ac.id ${ }^{2)}$, herriyusfi@fkip.unsri.ac.id ${ }^{3)}$
}

\begin{abstract}
ABSTRAK
Penelitian dan pengembangan ini bertujuan untuk mengembangkan teknik pembelajaran pasing bawah permainan bola voli untuk siswa SMP kelas VII sebagai solusi bagi guru dalam pembelajaran sehingga dapat meningkatkan hasil belajar peserta didik dalam pembelajaran pasing bawah bawah permainan bola voli. Pengembangan teknik pembelajaran pasing bawah dilakukan di SMP Negeri 1 Palembang dengan menggunakan metode penelitian research adn development dengan model ADDIE (Analysis, Design, Development or Production, Implementation or Delivery and Evaluations). Subjek dalam penelitian ini adalah siswa SMP N 1 Palembang Kelas VII angkatan 2018/2019. Teknik analisis data deskriptif dengan persentase. Hasil evaluasi satu-satu didapatkan dari guru PJOK adalah sebesar $80 \%$ sehingga produk dikategorikan layak, selanjutnya produk sudah dikatakan layak maka dilanjtkan dengan uji coba kelompok kecil pada 12 siswa/siswi kelas VII di dapatkan nilai pada ranah keterampilan pasing bawah sebesar 11 siswa $(91,66 \%)$ diujicobakan lulus KBM, sedangkan untuk penilaian ranah pengetahuan di dapatkan 11 siswa $(91,66 \%)$ lulus KBM, dari hasil penelitian ini maka produk pengembangan teknik pembelajara pasing bawah permainan bola voli "layak" digunakan untuk siswa SMP kelas VII. Temuan dalam penelitian ini adalah dihasilkannya 12 baru teknik pembelajaran pasing bawah yang dapat digunakan sebagai bahan ajar pembelajaran pasing bawah. Implementasi dari penelitian pengembangan ini adalah dapat digunakan oleh guru PJOK sebagai tambahan variasi teknik dalam mengajar pasing bawah permainan bola voli.
\end{abstract}

Kata kunci: Pengembangan Pembelajaran, Pasing Bawah, Bola voli

\section{PENDAHULUAN}

Pembelajaran PJOK disekolah masih minimnya pengetahuan guru PJOK dalam menerapkan dan mengembangkan model dan metode yang tepat dalam proses belajar mengajar pembelajaran di sekolah menengah pertama, keadaan ini disebabkan keterbatasan referensi atau sumber bacaan, kinerja guru penjas dirasa sangat kurang baik sesuai dengan pendapat (Damanik, Fadli, dan Suyono, 2016) menyatakan bahwa kinerja guru PJOK yang telah disertifikasi memilki kinerja pada kategori kurang, hal ini menunjukkan perlu adanya perbaikan. Menurut Subagiyo dkk (2008) pendidikan jasmani adalah latihan jasmani yang dimanfaatkan, dikembangkan, dan didayagunakan dalam pendidikan.

Penelitian research and development merupakan penelitian yang berorientasi untuk mengembangkan suatu produk. Penelitian pengembangan menghasilkan produk yang dapat langsung dimanfaatkan. Misalnya, mengembangkan dalam teknik pembelajaran. Hasil pengembangan akan diujicobakan kemudian direvisi sampai hasilnya dinyatakan layak untuk digunakan.

Pengembangan teknik pembelajaran pasing bawah bola voli berfungsi sebagai salah satu variasi teknik pembelajaran digunakan dalam pembelajaran permainan bola voli baik teori dan praktek sehingga pembelajaran diharapkan akan lebih efektif dan efisien sesuai dengan pendapat Gagne dan Brings (dalam Jamil Suprihatiningrum, 2012) hasil belajar adalah kemampuan-kemampuan yang dimilki siswa sebagai akibat perbuatan pembelajjaran dan dapat diamati.

Penelitian terdahulu bahwa peningkatan pembelajaran teknik dasar pasing dapat dilakukan dengan model pembelajaran tactical game (Nurhayati, 2017). Penelitian lain berhubungan dengan media yaitu pengembangan dalam pembelajaran bola voli adalah dengan pengembangan pembelajaran permainan bolavoli menggunakan media interaktif di SMP (Haryanto, Dwiyoga, dan Sulistyorini, 2015), selain itu pada penelitian (Syafaruddin, Hartati, Destriana, 2018) pengembangan multimedia pembelajaran dapat digunakan untuk meningkatkan hasil belajar mahasiswa khususny pembelajaran permainan bola voli. Melihat belum adanya pengembangan yang berhubungan dengan teknik pembelajaran maka penelitian pengembangan ini berusaha menghasilkan produk yang berbeda tentang pembelajaran pasing bawah. Perubahan yang terjadi dalam dunia pendidikan menuntut guru PJOK untuk memiliki teknik pembelajaran yang bervariatif. Pengembangan teknik pembelajaran yang bervariatif dapat membantu pendidik untuk mendesain pembelajaran secara kreatif agar proses pembelajaran menjadi inovatif, menarik, lebih berkualitas serta dapat meningkatkan hasil belajar peserta didik. Pengembangan teknik pembelajaran ini dikhususnya hanya pada materi pasing bawah pada permainan bola voli SMP kelas VII. 
Produk yang dikembangkan adalah pengembangan teknik pembelajaran dasar pasing bawah permainan bola voli SMP kelas VII berupa buku pembelajaran permainan bola voli yang merupakan salah satu bentuk dari bahan ajar. Berdasarkan teknologi yang digunakan (Direktorat Pembinaan Sekolah Menengah Atas, 2008) mengklasifikasikan bahan ajar menjadi empat kategori, yaitu bahan ajar cetak berupa handout, buku, modul, lembar kegiatan siswa, brosur, leaflet, wallchart, foto, dan model. Kontribusi dari penelitian pengembangan ini adalah sebuah produk pengembangan teknik pembelajaran pasing bawah yang dapat digunakan sebagai bahan mengajar guru PJOK ataupun pelatih olahraga permainan bola sebagai variasi bentuk-bentuk teknik pembelajaran pasing bawah.

\section{RUANG LINGKUP}

Permasalah ini mencakup tentang minimnya variasi teknik pembelajaran dalam permainan bola voli, pada penelitian ini akan dikembangkan beberapa teknik pembelajaran dalam permainan bola voli khususnya siswa kelas VII SMP. Adapun batasan masalah dari penelitian ini adalah sebatas pada bagaimana mengembangkan teknik pembelajaran pasing bawah permainan bola voli untuk siswa SMP kelas VII, selain itu apakah pengembangan teknik pembelajaran pasing bawah bola voli layak dan efektif digunakan bagi siswa SMP kelas VII. Penelitian ini diharapkan menghasilkan teknik pembelajaran tentang pasing bawah permainan bola pada SMP kelas VII berupa buku panduan pembelajaran.

\section{BAHAN DAN METODE}

Menurut Hamzah B.Uno (2011), teknik pembelajaran adalah jalan, alat, atau media yang digunakan pengajar guna mengarahkan kegiatan peserta didik pada harapan yang diinginkan atau dicapai. Sunardi dan Kardiyanto (2013) pasing bawah adalah teknik dasar permainan bolavoli dengan menggunakan kedua lengan bawah yang untuk mengoperkan bola kepada teman seregunya untuk dimainkan di area lapangan sendiri dan bertujuan sebagai awal untuk melakukan serangan awal pada regu lawan.

Pembelajaran merupakan penyampaian berbagai informasi dan aktifitas yang diarahkan untuk memudahkan pencapaian tujuan belajar secara spesifik dan diharapkan. Dimyati dan Mudjiono (2006), pembelajaran adalah kegiatan pengajar secara sistematis dalam desain instruksional untuk membuat peserta belajar secara aktif yang menekankan pada penyediaan sumber belajar.

Prosedur pengembangan dalam penelitian ini adalah metode research and Development (R\&D). Sugiyono (2013) menyatakan metode penelitian pengembangan adalah metode penelitian yang digunakan untuk menghasilkan produk tertentu, dan mengkaji keefektifan produk tersebut. Teknik analisis data digunakan analisis data kuantitatif dengan persentase. Persentase digunakan untuk mengetahui status sesuatu yang dipersentasekan dan ditampilkan dalam persentase. Penelitian pengembangan ini dilaksanankan di SMP $\mathrm{N} \quad 1$ Palembang Kelas VII semester 1 tahun ajaran 2018/2019. Langkah-langkah pengembangan dilaksanakan sesuai dengan Prosedur ADDIE, yakni (1) Analisis kebutuhan berupa observasi pembelajaran bola voli terutama materi pasing bawah yang dilakukan pada guru-guru PJOK, (2) Design (perencanaan) pengembangan produk awal berupa rancangan produk yang divalidasi oleh guru PJOK serta ahli dalam permainan bola voli, setelah dilakukan validasi dilakukan revisi rancangan produk, (3) Development dilakukan kegiatan evaluasi satu-satu dan ujicoba kelompok kecil dimana produk sudah dapat dikatakan layak dan efektif digunakan untuk pembelajaran. Penelitian ini hanya sampai langkah Development dikarenakan waktu penelitian yang sangat tidak memadai.

\section{PEMBAHASAN}

Pada penelitian ini sebelum dibahas mengenai pembahasan penelitian akan disajikan hasil penelitian pengembangan teknik pembelajaran pasing bawah SMP kelas VII.

\subsection{Hasil Pengembangan Teknik Pembelajaran}

\section{Pasing Bawah}

Hasil penelitian ini berupa analisis, design dan development pengembangan teknik pembelajaran pasing bawah

\section{Analisis}

Pembelajaran permainan bola voli pada materi bawah terlihat begitu monoton dengan menampilkan hanya 1-2 jenis teknik pembelajaran, kurang bervariasinya teknik pembelajaran pasing bawah hal ini menyebabkan kejenuhan pada beberapa siswa sehingga pembelajaran dirasa tidak maksimal. Dengan permasalah ini ditemukan minimnya teknik pembelajaran dalam pasing bawah. Analisi berikutnya adalah menentukan tujuan, tujuan dalam penelitian ini adalah untuk mengembangkan teknik pembelajaran pasing bawah bola voli permainan bola voli SMP kelas VII.

\section{Design (Perencanaan)}

Perencanaan adalah mengembangkan produk pembelajaran pasing bawah guna membantu guru SMP mengatasi permasalahan yang ditemui dalam pembelajaran teknik pasing bawah bola voli produk pengembangan masih berupa draf produk awal. Proses ini diawali dengan dilakukan validasi ahli pembelajaran dan permainan bolavoli.

\section{Validasi Ahli Permainan BolaVoli}

Pengembangan teknik pembelajaran pasing bawah SMP kelas VII divalidasi ahli permainan bola dan didapatkan hasil sebagai berikut 
Tabel 1. Hasil Penilaian Validasi Ahli Bola Voli

\begin{tabular}{|c|c|c|c|c|}
\hline $\begin{array}{c}\text { Kode } \\
\text { Ahli }\end{array}$ & $\begin{array}{c}\text { Nilai } \\
\text { Validasi }\end{array}$ & $\begin{array}{c}\text { Nilai } \\
\text { Max }\end{array}$ & $\begin{array}{c}\text { Persentase } \\
(\%)\end{array}$ & Kategori \\
\hline Ex 1 & 27 & 40 & $67,5 \%$ & $\begin{array}{c}\text { Cukup } \\
\text { layak }\end{array}$ \\
\hline
\end{tabular}

Persentase $=$ Jumlah/Nilai Maksimal

$$
\begin{aligned}
& =\frac{27}{40} \times 100 \% \\
& =67,5 \%
\end{aligned}
$$

Pada tabel 1.didapatkan 67,5\% (1) dengan demikian dapat dinyatakan bahwa menurut ahli permainan bola voli, pada tahap validasi pertama pengembangan teknik pembelajaran pasing bawah permainan bola voli dari aspek permainan bola voli mendapatkan kategori "cukup layak".

Tabel 2. Hasil Penilaian Validasi Ahli PJOK

\begin{tabular}{|c|c|c|c|c|}
\hline No & $\begin{array}{c}\text { Nilai } \\
\text { validasi }\end{array}$ & $\begin{array}{c}\text { Nilai } \\
\text { Max }\end{array}$ & $\begin{array}{c}\text { Persentase } \\
(\boldsymbol{\%})\end{array}$ & Kategori \\
\hline E 1 & 54 & 80 & 67,5 & $\begin{array}{c}\text { Cukup } \\
\text { Layak }\end{array}$ \\
\hline
\end{tabular}

Persentase $=$ Jumlah/Nilai Maksimal

$$
\begin{aligned}
& =\frac{54}{80} \times 100 \% \\
& =67,5 \%
\end{aligned}
$$

Pada validasi tahap pertama persentase yang didapatkan $67,5 \%$ (2) dengan demikian dapat dinyatakan bahwa menurut ahli PJOK, pada tahap validasi pertama pengembangan model pembelajaran bola voli dari aspek PJOK mendapatkan kategori "cukup layak". Penelitian ini dapat dilanjutkan dengan syarat bahwa draf produk harus direvisi terlebih dahulu sesuai dengan pendapat ahli sebelum diujicobakan.

\section{Development (Pengembangan)}

Berdasarkan prosedur pengembangan maka pelaksanaan pada tahap pengembangan ini akan dilakukan uji coba, yaitu evaluasi satu-satu dan ujicoba kelompok kecil. Persentase penilaian dari guru PJOK

$\frac{12}{15} \times 100 \%$

$=80 \%$

Dengan hasil one to one yang dilakukan pada guru PJOK didapatkan persentase sebesar $80 \%$ untuk pengembangan teknik pembelajaran pasing bawah dimana hasil ini termasuk pada kategori "Layak".

\section{Ujicoba Kelompok Kecil}

Penilaian hasil pembelajaran pasing bawah permainan bola voli dilakukan pada 2 ranah yaitu keterampilan dan sikap. Hasil penilaian terhadap 12 siswa/siswi pada 2 ranah, yaitu keterampilan dan sikap. Tabel di bawah ini adalah hasil penilaian keterampilan pasing bawah siswa SMP kelas 1.

Tabel 3. Presentase hasil tes keterampilan pasing bawah

\begin{tabular}{|c|c|c|c|}
\hline Nilai & $\begin{array}{c}\text { Jumlah } \\
\text { siswa }\end{array}$ & Kategori & Persentase \\
\hline $86-100$ & 3 & Sangat Baik & $25 \%$ \\
\hline $71,00-$ & 8 & Baik & $66,67 \%$ \\
85,99 & & Cukup & $8,33 \%$ \\
\hline $\begin{array}{c}56,00- \\
70,99\end{array}$ & 1 & Kurang & $0 \%$ \\
\hline $\begin{array}{c}41,00- \\
55,99\end{array}$ & 0 & $\begin{array}{c}\text { Sangat } \\
\text { Kurang }\end{array}$ & $0 \%$ \\
\hline$<40,99$ & 0 & \multicolumn{3}{|c}{} \\
\hline
\end{tabular}

Pada data ini didapatkan 11 siswa yang lulus KBM yaitu yang berada pada kategori sangat baik yaitu 3 siswa (25\%), kategori baik yaitu 8 siswa $(66,67 \%)$ dan yang tidak lulus KBM adalah 1 siswa $(8,33 \%)$. Secara klasikal pembelajaran dapat dikatakan tuntas karena sebanyak 11 siswa $(91,67 \%)$ dari 12 siswa yang diujicoba lulus KBM Tabel di bawah ini akan menggambarkan hasil penilaian sikap yang didapatkan melalui observasi yang dilakukan kepada kelompok ujicoba kelompok kecil

Tabel 4. Presentasi hasil observasi sikap pasing bawah

\begin{tabular}{|c|c|c|c|}
\hline Nilai & $\begin{array}{c}\text { Jumlah } \\
\text { siswa }\end{array}$ & Kategori & Persentase \\
\hline $86-100$ & 4 & Sangat Baik & $33,33 \%$ \\
\hline $71,00-85,99$ & 7 & Baik & $58,33 \%$ \\
\hline $56,00-70,99$ & 1 & Cukup & $8,34 \%$ \\
\hline $41,00-55,99$ & 0 & Kurang & $0 \%$ \\
\hline$<40,99$ & 0 & Sangat Kurang & $0 \%$ \\
\hline
\end{tabular}

Pada tabel 4. data ini didapatkan siswa yang lulus KBM adalah 11 siswa yaitu yang berada pada kategori sangat baik yaitu 4 siswa $(33,33 \%)$, kategori baik yaitu 7 siswa $(58,33 \%)$ dan yang tidak lulus KBM adalah 1 siswa $(8,34 \%)$. Secara klasikal siswa dikatakan tuntas, karena sebanyak 11 siswa $(91,66 \%)$ dari 12 siswa yang dilakukan ujicoba telah melebihi batas KBM.

\subsection{Pembahasan Pengembangan Teknik \\ Pembelajaran Pasing Bawah}

Menurut (Mulyatiningsih, 2011) "penelitian dan perkembangan bertujuan untuk menghasilkan produk baru melalui proses pengembangan". Langkah-langkah penelitian pengembangan dalam penelituian ini menggunakan model pengembangan ADDIE.

Jika guru tidak mampu menghadirkan pembelajaran yang efektif, maka akan menyebabkan hilangnya peluang emas untuk meraih keuntungan semaksimal 
mungkin dari pengajaran pendidikan jasmani sebagai medium pendidikan (Rukmana, 2008). Branch (2009) "Generate goals that respond to performance gaps that are caused by a lack of knowladge and skill", tujuan pengajaran adalah menghasilkan respon kesenjangan kinerja yang disebabkan kurangnya pengetahuan dan keterampilan. Analisis berikutnya adalah menentukan tujuan, tujuan dalam penelitian ini adalah untuk mengembangkan teknik pembelajaran pasing bawah bola voli permainan bola voli SMP kelas VII. Dengan pengembangan ini diharapkan dapat menambah jumlah variasi teknik pembelajaran dalam permainan bola voli khususnya pasing bawah. Berdasarakan studi kepustakaan mengenai dasar-dasar teori pembelajaran pasing bawah selanjutnya adalah menentukan tujuan pengembangan produk, memilih cakupan materi, mencari bahan materi dan beberapa hal lainnya yang terkait dengan pengembangan produk pasing bawah.

Perancangan adalah langkah setelah melakukan analisis, penelitian dimulai dengan mengembangkan suatu produk guna membantu guru SMP mengatasi permasalahan yang ditemui dalam pembelajaran teknik pasing bawah bola voli produk pengembangan masih berupa draf produk awal dan dalam pengembangannya, sebelum dilakukan uji coba kelompok kecil terhadap produk awal, produk harus mendapat validasi dari ahli materi.

Berdasarkan hasil validasi yang diberikan oleh ahli permainan bola voli pada tahap pertama persentase nilai yang didapatkan 67,5\%, dengan demikian dapat dinyatakan bahwa pada validasi tahap pertama pengembangan teknik pembelajaran pasing bawah permainan bola voli dari aspek permainan bola voli mendapatkan kategori "cukup layak" akan tetapi buku pembelajaran pasing bawah sedikit revisi mengenai model pemanasan dan pendinginan lebih diperjelas dan disederhanakan bahasa instruksi pelaksanaanya menurut rekomendasi dari ahli permainan bola voli.

Hasil validasi ahli permainan bola voli untuk teknik pengembangan pembelajaran pasing bawah didapatkan 67,5\% dan untuk pasing atas adalah 70\% maka dari hasil ini berada pada kategori "cukup layak" atau produk dapat digunakan secara bersyarat. Pada validasi tahap pertama persentase yang didapatkan $67,5 \%$ dengan demikian dapat dinyatakan bahwa menurut ahli PJOK, pada tahap validasi pertama pengembangan teknik pembelajaran passing bawah bola voli dari aspek PJOK mendapatkan kategori "cukup layak". Revisi yang direkomendasikan yaitu cover dan gambar pelaksanaan teknik perlu di didesain lebih menarik. Gerakan-gerakan pemasanan perlu disederhanakan agar waktu pemansan tidak terlalu lama.

Evaluasi satu-satu ini dilakukan oleh 1 orang guru PJOK. Tujuan dari evaluasi ini adalah untuk mendapatkan pendapat dari guru PJOK SMP N 1 Palembang pada teknik pembelajaran pasing bawah bola permainan bola voli. Dengan hasil one to one evaluation yang dilakukan pada guru PJOK didapatkan persentase sebesar $80 \%$ untuk pengembangan teknik pembelajaran dimana hasil ini termasuk pada kategori "Layak" sehingga dapat diteruskan pada tahap berikutnya yaitu small group.

Uji coba kelompok kecil dilakukan pada 12 siswa/siswi kelas VII SMP N 1 Palembang. 12 siswa kelas VII SMP N 1 Palembang dipilih secara heterogen yaitu siswa yang berkemampuan tinggi, sedang dan rendah, dimana 12 siswa tersebut dipilih oleh guru mata pelajaran PJOK kelas VII. Pada tahap ujicoba ini guru PJOK menggunakan pengembangan teknik pembelajaran pasing bawah dalam pembelajaran bola voli. Uji coba kelompok kecil ini dilakukan pada 2 pertemuan pembelajaran (6JP), yaitu pada pertemuan pertama menggunakan pengembangan teknik pasing bawah untuk materi pembelajaran pasing bawah pertemuan kedua dilakukan penilaian untuk melihat efektifitas produk yang dikembangkan.

Penilaian dilakukan pada 2 ranah yaitu keterampilan dan sikap. Penilaian ini digunakan untuk melihat sejauh mana pengembangan pembelajaran teknik ini digunakan oleh guru PJOK dalam proses pembelajaran permainan bola voli dan melihat hasil pembelajaran siswa. Dengan dilakukannnya penilaian maka dapat memperbaiki serta meminimalisir kekurangan pada pengembangan teknik pasing bawah tersebut. Hasil penilaian terhadap 12 siswa/siswi pada 2 ranah, yaitu keterampilan dan sikap.

Tes keterampilan dilakukan dengan mengambil penilaian dalam proses gerakan pasing bawah. Sesuai hasil penilaian gerak dasar passing bawah diperoleh hasil sebanyak 11 siswa yang lulus KBM yaitu yang berada pada kategori sangat baik yaitu 3 siswa (25\%), kategori baik yaitu 8 siswa $(66,67 \%)$ dan yang tidak lulus KBM adalah 1 siswa $(8,33 \%)$. Secara klasikal pembelajaran dapat dikatakan tuntas karena sebanyak 11 siswa $(91,67 \%)$ dari 12 siswa yang diujicoba lulus KBM, maka produk berupa pengembangan teknik pembelajaran pasing bawah permainan bola voli valid, efektif dan efisien untuk meningkatkan hasil pembelajaran khususnya ranah keterampilan gerak,

Menurut (Mardapi, D 2012) penilaian ranah afektif siswa dapat menggunakan kuesioner dan dilakukan melalui observasi atau pengamatan, maka dalam penelitian ini untuk melihat hasil pembelajaran pada ranah sikap dilakukan dengan observasi. Pada data ini didapatkan siswa yang lulus KBM adalah 11 siswa yaitu yang berada pada kategori sangat baik yaitu 4 siswa $(33,33 \%)$, kategori baik yaitu 7 siswa $(58,33 \%)$ dan yang tidak lulus KBM adalah 1 siswa $(8,34 \%)$. Secara klasikal siswa dikatakan tuntas, karena sebanyak 11 siswa $(91,66 \%)$ dari 12 siswa yang dilakukan ujicoba telah melebihi batas KBM maka produk berupa pengembangan teknik pembelajaran pasing bawah dikatakan valid, efektif dan efisien untuk meningkatkan hasil pembelajaran khususnya ranah sikap. 


\section{KESIMPULAN}

Penelitian dan pengembangan teknik pembelajaran pasing bawah permainan bola voli pada SMP Kelas VII SMP Negeri 1 Palembang menggunakan model ADDIE. Pada langkah development yaitu ujicoba kelompok kecil didapatkan hasil tes keterampilan dan sikap pada pasing bawah diperoleh rata-rata $91,67 \%$ atau berada pada kategori "Layak". Produk berupa pengembangan teknik pembelajaran dan pasing bawah dikatakan valid, efektif dan efisien untuk meningkatkan hasil pembelajaran khususnya ranah sikap dan keterampilan. Implikasi dari pengembangan ini adalah dapat digunakan guru PJOK dalam pembelajaran pasing bawah SMP Kelas VII, adapun kontribusi dari pengembangan ini dapat meningkatkan variasi teknik pembelajaran pasing bawah permainan bola voli.

\section{SARAN}

Penelitian ini diharapkan dapat berkontribusi bagi perkembangan dan kemajuan dunia pendidikan khususnya dalam bidang pendidikan jasmani, olahraga, dan kesehatan. Pengembangan ini diharapkan dapat memberi variasi-variasi dalam teknik pembelajaran permainan bola voli. Penelitian ini dapat diteruskan pada pengembangan teknik pembelajaran dengan langkahlangkah atau metode pengembangan lain.

\section{DAFTAR PUSTAKA}

Branch. 2009. Instructional Design-The ADDIE Approach. New York: Springer.

Direktorat jenderal manajemen pendidikan dasar dan menengah direktorat pembinaan sekolah menengah atas. 2008. Panduan Penulisan butir soal departemen pendidikan nasional.

Endang Mulyatiningsih. 2011. Metode Penelitian Terapan Bidang Pendidikan. Bandung: Alfabeta.

Hamzah B. Uno dan Nurdin Mohamad. 2011. Belajar dengan Pendekatan Pembelajaran Aktif Inovatif Lingkungan Kreatif Efektif, Menarik. Jakarta. Bumi Aksara.

Jamil Suprihatiningrum. 2012. Strategi Pembelajaran Aktif. Yogyakarta: A-Ruzz Media.

Mardapi, D. 2012. Pengukuran Penilaian \& Evaluasi Pendidikan. Yogyakarta: Nuha Medika.

Maya Nurhayati. 2017. Implementasi Model Pembelajaran Tactical Game Terhadap Hasil Belajar Teknik Dasar Passing Bawah Permainan Bola Voli Pada Siswa Sekolah Menengah Pertama. Jurnal Educatio Vol 2 No 1, ISSN: 2548-6756, Hal 1-8.

M. Taufik Hidayat. 2015. Peningkatan Kemampuan Pass Bawah Dalam Permainan Bola Voli Melalui Latihan Pass Bawah Duduk Berdiri Pada Bangku Dan Pass Bawah Dengan Berjalan Pada Siswa Kelas Vi Sdn Tanggul Wetan 01 Jember. Jurnal Pancaran Pendidikan Vol 4 No 1, ISSN: 0852601X, Hal. 153-164.
Rukmana, Anik. 2008. Pembelajaran Pendidikan Jasmani Di Sekolah Dasar. Jurnal pendidikan dasar. Bandung: Universitas Pendidikan Indonesia.

Saipul A Damanaik, Zen Fadli, dan Hadi Suyono. 2016. Kinerja Guru Pendidikan Jasmani Kesehatan Olahraga yang Sudah Disertifikasi. Jurnal penelitian bidang pendidikan. Vol 22 No 2 ISSN: 2502-7182, Hal 139-134.

Sugiyono. 2013. Metodelogi Penelitian Kuantitatif Kualitatif Dan R\&D. Bandung: Alfabeta.

Sunardi dan Kardiyanto, D.W. 2013. Bolavoli. Surakarta: UNS Press.

Syafaruddin, Hartati \& Destriana. 2018. Development of interactive multimedia the subjects course of work. International Journal of physical education, sport, and health Vol 5 Issue 2, Part A Pag. 01-03. http://www.kheljournal.com/archives/?year $=2018 \&$ vol=5\&issue $=2$ \&part $=\mathrm{A} \quad$ (diakses tanggal 12 Oktober 2018)

Try Sevita Haryanto, Wasis Djoko Dwiyogo \& Sulistyorini. 2015. Pengembangan pembelajaran Permainan Bolavoli menggunakan media interaktif di SMP Negeri 6 Kabupaten di Situbondo. Jurnal Pendidikan Jasmani Vol 25 No 1 ISSN: Page 123-128.

\section{UCAPAN TERIMA KASIH}

Terimah kasih kepada Rektor Universitas Sriwijaya yang telah memberikan dana hibah penelitian satek sehngga penelitian ini dapat terlaksana. Terima kasih kepada kepala sekolah, guru PJOK di SMP N 1 Palembang yang telah membantu dalalm peneltian ini, serta rekan-rekan sejawat yang telah membantu dalam pelaksanaan penelitian ini. 